\title{
Modelling Determinants of Tree Planting and Retention on Farm for Improvement of Forest Cover in Central Kenya
}

\author{
Vincent Onguso Oeba, ${ }^{1}$ Samuel C. J. Otor, ${ }^{2}$ James B. Kung' ${ }^{2}{ }^{2}$ and M. N. Muchiri' \\ ${ }^{1}$ Kenya Forestry Research Institute, P.O. Box 20412-00200, Nairobi, Kenya \\ ${ }^{2}$ Department of Environmental Sciences, School of Environmental Studies, Kenyatta University, P.O. Box 43844-00100, Nairobi, Kenya
}

Correspondence should be addressed to Vincent Onguso Oeba, voeba@yahoo.co.uk

Received 31 October 2012; Accepted 27 November 2012

Academic Editors: H. Höfer and M. Kanashiro

Copyright (C) 2012 Vincent Onguso Oeba et al. This is an open access article distributed under the Creative Commons Attribution License, which permits unrestricted use, distribution, and reproduction in any medium, provided the original work is properly cited.

\begin{abstract}
Farm forestry has proved to be an important enterprise for small- and large-scale farmers worldwide. It has the potential of improving forest/tree cover across the globe. In Kenya, the forest cover is less than $2 \%$. The country envisions achieving $10 \%$ forest cover over the next decade through promotion of farm forestry. However, the decision to plant trees on farmers' land could be difficult. The study aimed to analyze the determinants of tree retention on farm for improvement of forest cover. Stratified and simple random sampling techniques were used in selecting 209 farmers. The results showed that sites, land size, age, education level, monthly income, tree management, extension services, availability of markets, harvesting regulation, and aesthetic and environmental motivation were significant determinants of tree retention. In particular, the chances of farmers who had gained technical skills in tree management were about 2.2 times higher to retain trees as compared to those who had not acquired such skills. Similarly, chances of farmers motivated to plant trees for environmental conservation were about 3.5 times higher to retain trees as compared to the group of farmers planting trees as a source of livelihood. These determinants would be instrumental in strengthening the current policies and reforms in forestry and agricultural sectors to enable Kenya to achieve $10 \%$ of forest cover.
\end{abstract}

\section{Introduction}

Farm forestry in the context of evergreen agriculture is emerging as an affordable and accessible science-based solution to caring better for the land and increasing smallscale food production [1]. It combines trees and food crops with principles of conservation farming. It has proved to be an important enterprise for small and large-scale farmers in low, medium and high potential areas worldwide [2]. In particular, it offers multiple benefits to farmers. This includes sources of green fertilizer, livestock fodder, timber, and fuel wood. Farm forestry has also other environmental benefits such as greater resilience to climate change and carbon storage, shelter, erosion control, watershed protection, and increased biodiversity [1].

The success of farm forestry may be assessed in terms of effects of various determinants such as advanced use of farm labour, positive environmental changes, increased financial returns among others [3]. When attempting to judge whether farm forestry is successful, it is important to note that the people involved may change their objectives over the years. For instance, markets may alter and force changes to the products required implying that as the farm business changes, economic calculations of the farm forestry enterprise will need to be adjusted. Successful farm forestry is therefore perhaps best seen as an incremental improvement and likelihood of long-term profitability and sustainability. Other studies by [4-7] reported that farmer's age, farm size, land value, erosion rate, tenure system, expected net returns/resource endowment, site description/biophysical factors, and market incentives as factors that influenced tree growing. In particular, secure land tenure significantly influenced tree planting practices as renters were less likely to adopt medium- or long-term conservation practices. Farmers who invested in timber stand improvement could improve the value of a stand and subsequent income from harvesting. This implied that forestland owners who derived significant income from their trees and viewed their 
forests as sources of income to be tapped periodically for income would engage in practices that would maintain or enhance income generating opportunities. Conversely, forestland owners who did not view their trees as a source of substantial income would have less incentive to invest in forestland. In the same vein, land-owners who claimed to be interested in aesthetics or enjoying woods generally had higher volumes per hectare than those who owned woods as part of their farm.

The developing countries in sub-Saharan Africa have continued to experience forest destruction as a result of uncontrolled timber harvesting, conversion of forests to farm and pasture lands, increased needs of human population, migration, education, energy prices, road construction, fire outbreaks, and other related mortality factors [8-10]. For example, farm households that occupied land illegally or insecure land title deeds were more likely to clear forests for agricultural expansion. In particular, Kenya is among developing countries in sub-Saharan Africa that shares problems of deforestation with other eastern Africa nations due to conversion of forests to other land use especially agriculture and settlement to meet the needs of ever increasing human population. The country is currently considered a low forest cover. The remaining natural forests have been degraded and can no longer provide sustainable supply of water, raw materials and other services. Clearing of woodlands in dry areas for charcoal production has led to environmental degradation. Further, trees on farmlands and industrial plantations have been overcut resulting in widening gap between the supply and demand for forest products [11].

As a result, the Government of Kenya has developed various strategies to counter the decrease of forest cover in the country. The first one was ban of tree harvesting in the state forests in 1999. Since then, the country has been sourcing domestic and industrial wood from farms, supplemented with timber imported from neighbouring countries. This strategy has seen the country over depending on farms for forest products which, has led to depletion of farmland wood stock [11]. The country therefore, requires to urgently intensifying tree planting on farms to restock tree cut as well as increase the forest cover. The Sessional Paper No. 1 of 2007 on Forest Policy and Forests Act 2005 emphasizes the development of farm forestry as a way of increasing low forest cover, diversifying subsistence products and income, while contributing to soil and water conservation $[11,12]$. It also points out the need to support farmers with sound management, utilization principles, incentives, information, better germ plasm and marketing strategies. Similarly, the Agriculture (CAP 318) on Farm Forestry Rules 2009 stipulates a 10 per cent forest cover on farms. The other strategies are described in various government blue prints such as Vision 2030 where the Ministry of Youth Affairs and Sports (MOYAS) developed an ambitious programme of trees for job. This was meant to encourage the youth in tree planting and nurturing for pay with a main aim of creating employment and conserving the environment.

Since inception of these strategies in Kenya, limited studies have been carried out to assess factors associated with tree planting and retention by farmers in order to realize the expected output of improving tree/forest cover. The decision by farmers to plant trees may be difficult due to many land use needs especially agriculture in enhancing food security of about 40 million Kenyans. Subsequently, land size for farm forestry has continued to shrink as a result of high land fragmentation and settlement, unsupportive land tenure arrangements whereby women, married sons and other landless have limited access to land for either tree planting or management of naturally growing woodlands [12-14]. Also there are gaps on adequate knowledge and understanding of the tree enterprise, which has been predominantly linked to supply driven research, markets, ineffective extension services and lack of user friendly packaging of the relevant information on the available technologies [12]. These are likely to pose serious challenges on Kenya's ambitious tree planting programme on farmlands for attaining $10 \%$ forest cover. It is on this background that we designed this study in order to evaluate various determinants such as demographic characteristics of farmers, land ownership, tree management and economic benefits of tree growing that would be crucial in developing approaches of improving forest cover. Therefore, the main objective of this study was to identify and analyze the determinants of tree retention on farm for improvement of forest cover in Central Kenya. The findings are expected to help the government of Kenya in mainstreaming strategies for forestry and agriculture policies in improving forest cover.

\section{Materials and Methods}

2.1. Study Area. Kenya is divided into 47 Counties [15]. Central Kenya has five Counties, namely, Nyandarua, Nyeri, Kirinyaga, Murang'a and Kiambu. In this region of Central Kenya, there is evidence of high land fragmentation and continuous farming causing a lot of pressure on natural and plantation forests as well as partial woodlands for settlement. Human encroachment and destruction of existing forests in Aberdares and Mt. Kenya ecosystems are on continuously rising. Therefore, this area was a selected for a case study to identify determinants of tree retention for improvement of forest cover in Central Kenya. The study sites were situated in Lari and Kikuyu districts in Kiambu County as well as Nyeri South and Nyeri North districts in Nyeri County.

\subsubsection{Nyeri South and Nyeri North Districts of Nyeri County.} Nyeri North comprises the most western part of the moist windward side of Mt. Kenya, the drier western leeward side of the extinct volcano and the borders of the semi-arid Laikipia Plateau. Nyeri South comprises the moist windward eastern slope of the Aberdare Range (Figure 1). The average annual rainfall ranges from $2200 \mathrm{~mm}$ on the most easterly exposed edge of the Aberdare range to $700 \mathrm{~mm}$ on the Laikipia Plateau. The altitude ranges from 2100 to $2400 \mathrm{~m}$. a.s.l. It is the most expansive and vast area in Central highlands of Kenya covering $3,284 \mathrm{~km}^{2}$. It's high densely populated area. In all divisions (Kieni West, Kieni East, Mathira, Mukurweini, Tetu, and Othaya) except Kieni West and Kieni 


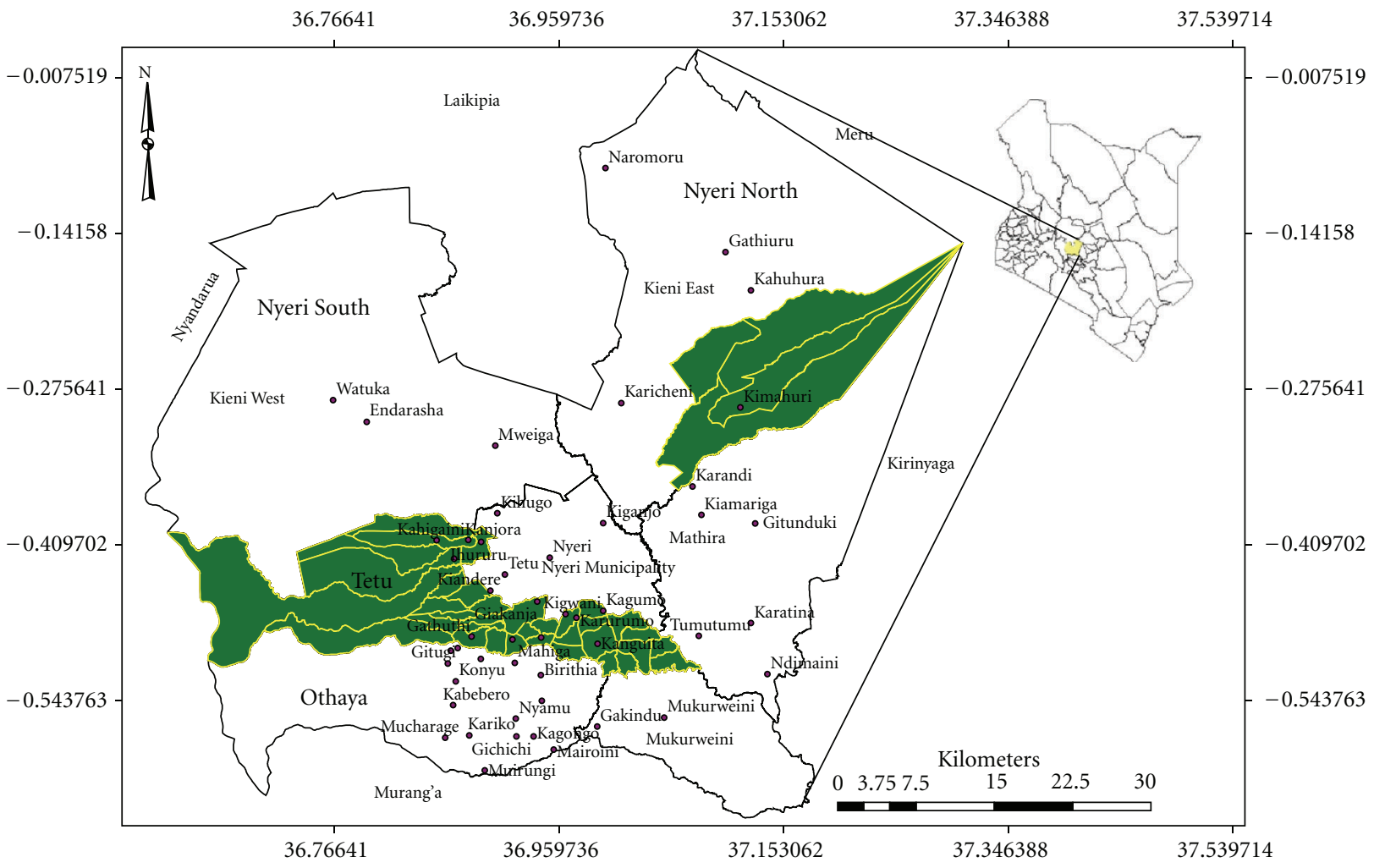

FIgURe 1: Map showing Nyeri South and Nyeri North districts in Nyeri County.

East, which are generally semi-arid, available agricultural land is less than 0.88 ha per household [16].

\subsubsection{Lari and Kikuyu Districts of Kiambu County. Kiambu's} agroecological zone (AEZ) extends in a typical pattern along the eastern slopes of the Aberdare Range. It is the most densely populated area with 640 persons per $\mathrm{km}^{2}$ in 2009 compared to 562 persons per $\mathrm{km}^{2}$ in 1999 and 280 persons per $\mathrm{km}^{2}$ in 1979 . It occupied $1323.9 \mathrm{~km}^{2}$ as compared to $2448 \mathrm{~km}^{2}$ in 1979 implying a great decrease of agricultural land size holding per person. Also due to its combination of good soils, climate and proximity to Nairobi, the country's main market, makes Kiambu the most economic farming region in the country [16].

Lari district lies on the upper highland AEZ one (UH $1)$. It is classified as sheep and dairy zone with permanent cropping possibilities, dividable in a long cropping season followed by medium one. It ranges from 2415 to $2591 \mathrm{~m}$ a.s.l and receives 1150 to $1276 \mathrm{~mm}$ mean annual rainfall. Kikuyu district lies on the lower highland AEZ two (LH 2) Figure 2. It is grouped as wheat/maize-pyrethrum zone with a medium to short and a weak short cropping season. It lies on $2067 \mathrm{~m}$ a.s.l receiving $1000 \mathrm{~mm}$ mean annual rainfall. It extends to the drier area of Karai and Kikuyu escarpments [16].

2.2. Sampling of Farm Households and Data Collection. A sampling frame was designed in all study areas where a list of farmers who planted over one hundred trees or at least a quarter an acre under woodlot or plantations was drawn.
Farmers were then stratified according to land sizes, tree planting densities, and species diversity varying from intense boundary planting, woodlots to plantation. To quantify the area under trees for cases of boundary planting conversions were done to assume uniform area under trees. This was equated as either a woodlot or a plantation of 0.5 ha. In each stratum, a list of farmers was drawn and each individual farmer was assigned random number. The random numbers were then ranked and targeted numbers of farmers were selected using the simple random sampling. Questionnaires were then allocated proportionately in each of the stratified category resulting to selection 209 respondents. A total of 48, 79,48 , and 34 questionnaires were allocated to Nyeri South, Nyeri North, Lari and Kikuyu districts, respectively. The data collected were mainly on household and farm characteristics. Data collectors were trained before carrying out the survey. Pre-testing was done to ensure consistency, reliability, and validity of the instrument.

2.3. Data Analysis and Model Applications. The selections of determinants used in this study were based from government of Kenya blue prints and authors conceptualization from cited literature. These were broadly classified as: demographic characteristics, land ownership and land use, tree planting on farm and use, problems of tree planting, tree management, social function of farm forestry, and economic benefits of trees on farm. In each of these classes, specific variables were assessed in relation to tree planting and retention. It was hypothesized that the likelihood of the 


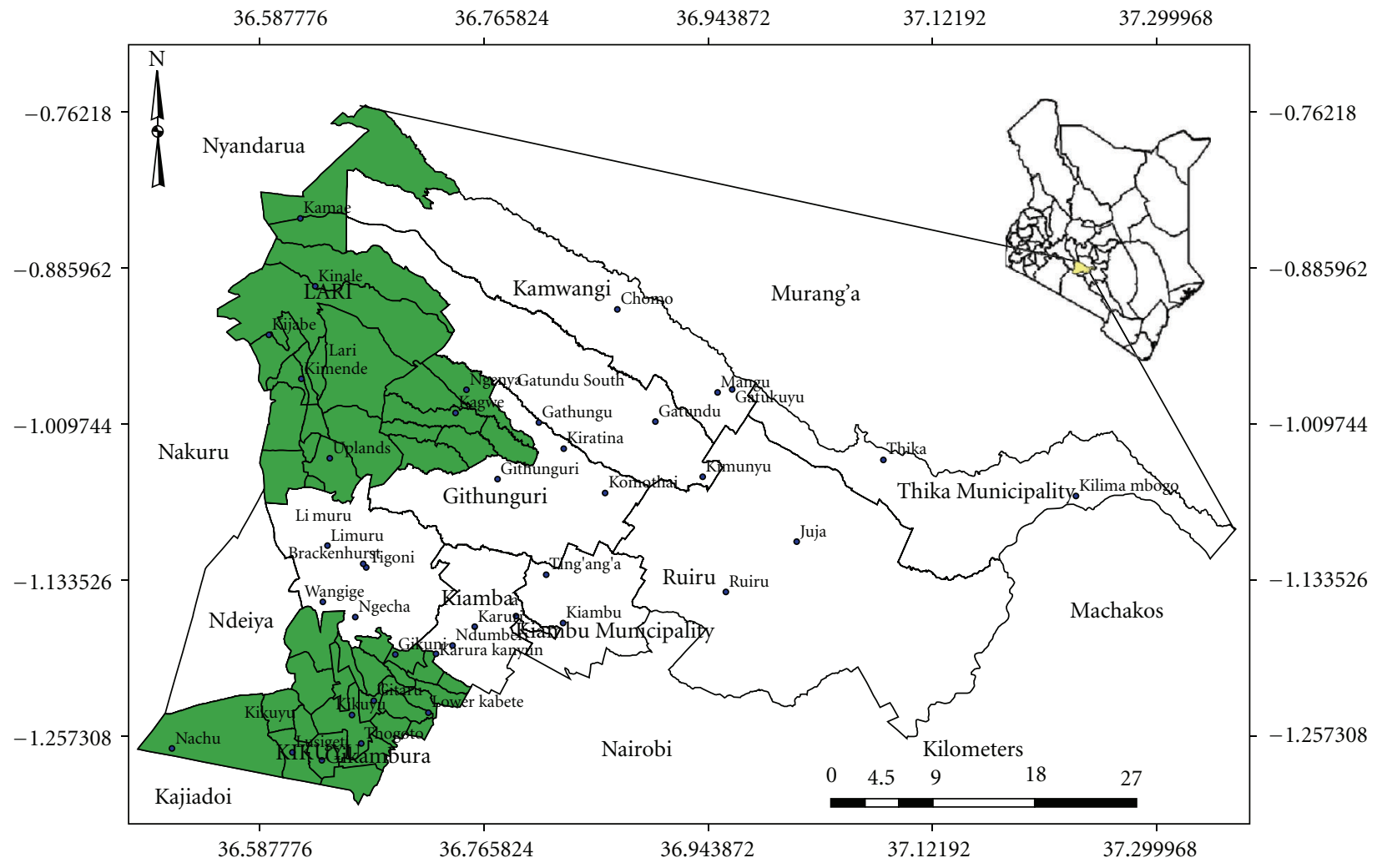

Figure 2: Map showing Lari and Kikuyu districts in Kiambu County.

farmer willing to retain trees on farm would be influenced by a number of determinants in each of the seven broad categories. Tree retention was assessed on the basis of farmers' frequency of tree planting in at least 10 years where a sample of data of tree planting was taken from 2004 to 2010 based on the respondent's recall. The other attributes considered for tree retention included; availability of different tree sizes on farms, species diversity of different growth rates, available plans of land use management, and willingness to invest in tree farming. In this case a group of farmers were considered to most likely or likely to retain trees on their farms if it was found that they were planting trees yearly on their farms, there were different trees on their farm of difference sizes (small diameters $<10 \mathrm{~cm}$, medium diameter $10-20 \mathrm{~cm}$, and large ones $>20 \mathrm{~cm}$ ) some ready for harvesting but farmer not willing to cut because of some reasons. The other measure of retention especially for large scale planting was indirect benefits of tree planting such as carbon credits. In this regard group farmers had anticipated of accessing carbon market with the understanding that they were not likely to harvest their trees after some period of time where they would be compensated with payment of carbon credits. This was observed in farmers' field where some had started shifting to planting of indigenous trees which have slow growth rate and likely to be in a long period of time on their farms. The other characteristics of tree retention were based on the fuelwood demand and regulation mechanisms by Kenya Forestry Service (KFS) where farmers ensured that any given time, they had trees on their farms to meet the increasing needs of various household demands. This was evidenced from the pattern of planting. It is in this respect that retention was measured as a latent variable but categorized into three or two levels farmers who were most likely, less likely and not likely; likely and not likely to plant and retain trees on farm as the dependent variable. This classification lead to the use of multinomial and binary logistic regression models, respectively. A criterion based on land size, age of the farmers, species diversity on farm, last period/frequency of tree planting, land use management priorities, hindrances of tree planting, and tree harvesting regimes was used to group farmers as "not likely", "likely", and "most likely" to retain trees on farm. Table 1 provides the description of the determinants hypothesized to influence the likelihood of tree planting and retention.

2.3.1. Descriptive Statistics. Chi-square statistical test and percentage frequencies were used to explore the association between the likelihood of tree retention and selected determinants. In order to control multi-collinearity among determinants, correlation analysis was performed in order to identify correlated variables before fitting the models.

2.3.2. Multinomial and Binary Logistic Regression Analysis. In order to examine the probability and extent at which the farmers were willing to retain trees on farm, multinomial and binary logistic regression models were used. In particular, when the dependent variable was in three categories, 
TABLe 1: Definitions and description of modelling variables.

\begin{tabular}{|c|c|c|}
\hline Variables & Description & Dummy description \\
\hline \multicolumn{3}{|l|}{ Dependent variable: } \\
\hline $\begin{array}{l}\text { Farmer's tree retention on } \\
\text { farm }\end{array}$ & $\begin{array}{l}\text { Farmer classified as most likely, less likely and not likely to retain } \\
\text { trees on farm or likely and not likely to retain trees on farm }\end{array}$ & $\begin{array}{l}0=\text { not likely; } 1=\text { less } \\
\text { likely; } 3=\text { most likely or } 0= \\
\text { not likely, and } 1=\text { likely. }\end{array}$ \\
\hline \multicolumn{3}{|l|}{ Explanatory variables: } \\
\hline Occupation $\left(X_{1}\right)$ & $\begin{array}{l}\text { Main occupation of the household head classified as either formal } \\
\text { employment or non-formal employment }\end{array}$ & $\begin{array}{l}1=\text { Formal; } 2= \\
\text { non-formal; } 0=\text { otherwise }\end{array}$ \\
\hline Age $\left(X_{2}\right)$ & Age of the household head & \\
\hline Education $\left(X_{3}\right)$ & Education level of the household head & $\begin{array}{l}1=\text { Formal learning; } 0= \\
\text { otherwise }\end{array}$ \\
\hline Marital status $\left(X_{4}\right)$ & Marital status of the head of household & $1=$ Married $; 0=$ Single \\
\hline Number household $\left(X_{5}\right)$ & Number of members of the household & \\
\hline Income $\left(X_{6}\right)$ & Income of the household head & \\
\hline Land $\left(X_{7}\right)$ & Land ownership of the household head & $\begin{array}{l}1=\text { Household that owns } \\
\text { land; } 0=\text { otherwise }\end{array}$ \\
\hline Land size $\left(X_{8}\right)$ & Land size owned by household members & \\
\hline Landuse $\left(X_{9}\right)$ & Area of land under trees & $\begin{array}{l}1=\text { Area under trees; } 0= \\
\text { otherwise }\end{array}$ \\
\hline Tree use $\left(X_{10}\right)$ & Purpose of trees planted on farm & 1 = Fuelwood; 2 = Aesthetic \\
\hline Technical skills $\left(X_{11}\right)$ & Provision of technical skills on tree management & $\begin{array}{l}1=\text { Received technical } \\
\text { skills; } 0=\text { otherwise }\end{array}$ \\
\hline Labour $\left(X_{12}\right)$ & Labour involvement on tree management & $\begin{array}{l}1=\text { intensive; } 0=\text { Not } \\
\text { intensive }\end{array}$ \\
\hline Extension services $\left(\mathrm{X}_{13}\right)$ & Accessing regular extension services & $\begin{array}{l}1=\text { Accessed extension } \\
\text { services; } 0=\text { otherwise }\end{array}$ \\
\hline Regulation $\left(X_{14}\right)$ & Regulation by KFS on tree harvesting & $\begin{array}{l}1=\text { Supports KFS } \\
\text { regulation; } 0=\text { otherwise }\end{array}$ \\
\hline Forest association $\left(X_{15}\right)$ & Existence and participation on forest organization & $\begin{array}{l}1=\text { Existence of forest } \\
\text { association; } 0=\text { otherwise }\end{array}$ \\
\hline Marketability $\left(X_{16}\right)$ & Knowledge and access to markets and policies & $\begin{array}{l}1=\text { Ready market; } 0= \\
\text { otherwise }\end{array}$ \\
\hline Economic motivation $\left(X_{17}\right)$ & Economic returns from tree growing & $\begin{array}{l}1=\text { High returns; } 0= \\
\text { otherwise }\end{array}$ \\
\hline
\end{tabular}

"not likely", "likely", and "most likely," multinomial logistic regression model of the form below was used:

$$
\begin{aligned}
\ln \left[\frac{p_{j}}{1-p_{j}}\right] & =P(\text { FRT }) \\
& =\frac{1}{1+\exp \left\{-\left(\beta_{0}+\beta_{1} X_{1}+\cdots+\beta_{n} X_{n}\right)\right\}},
\end{aligned}
$$

where $j=3$ ( $1=$ not likely, $2=$ less likely, and $3=$ most likely), $P($ FRT $)=$ the probability of the farmer willing to retain trees on farm, $0 \leq \mathrm{FRT} \leq 1 \beta_{0}=$ intercept, $\beta_{1}+$ $\cdots+\beta_{n}=$ set of $17(n=17)$ regression coefficients of the determinants as provided in Table $1, X_{1}+\cdots+X_{n}=$ set of $17(n=17)$ determinants as provided in Table 1 and $\exp =$ base of the natural logarithm.

When $j=2$, $(1=$ not likely and $2=$ likely $)$ the multinomial logistic model was an estimate of binary logistic regression model.
Both multinomial and binary logistic regression models assumed that there exists an index/a desire or intent by the farmer to retain trees on farm which was a linear function of the vector of predictors expressed as

$$
I_{t}=X_{t} \beta
$$

where $I_{t}=(1 \times 1)$ latent determinant that is unobservable or index of intent/desire to retain trees by farmer $t ; X_{t}=(1 \times k)$ vector of observations on 17 determinants for farmer $t$; and $\beta=(k \times 1)$ vector of coefficients.

If this index exceeds the individual threshold, retention of trees occurs.

Similarly, extend of planting trees was also a function of the determinants, through the index. The greater desire to plant trees on farm, the greater the extent of retaining:

$$
y_{t}=0 \quad \text { if } I_{t}<I_{t}^{*}=I_{t}-I_{t}^{*} \quad \text { if } I_{t}>I_{t}^{*},
$$


where $y_{t}=(1 \times 1)$ dependent variable representing extent of planting trees on farm by farmert; $I_{t}^{*}=(1 \times 1)$ critical threshold or limiting factor for famer $t$.

Essentially, each farmer may have a different value. For instance, if extension services are a significant determinant (predictor variable), then more of the extension services may be required to push one farmer over threshold than that required to induce another farmer's retaining ability. Since individual threshold differ, at any given index value, there will be both a concentration of zeros (for non-retaining) and a distribution of positive extents of retaining (for those who would retain). Therefore the probability of planting and retaining trees, given a particular index value was given by

$$
\begin{gathered}
\operatorname{Prob}\left\{y>\frac{0}{I}\right\}=\operatorname{Prob}\left\{I^{*}<\frac{1}{I}\right\}=F\left(\frac{1}{I}\right), \\
\operatorname{Prob}\left\{y=\frac{0}{I}\right\}=\operatorname{Prob}\left\{I^{*}>\frac{1}{I}\right\}=1-F\left(\frac{I}{\delta}\right),
\end{gathered}
$$

where $F(I / \delta)$ is the value of the standard normal cumulative distribution at $I / \delta$.

Expected extend of the planting and retaining, given a particular index value was given by

$$
E\left(\frac{y_{t}}{I_{t}}\right)=I F\left(\frac{I_{t}}{\delta}\right)+\delta F\left(\frac{I_{t}}{\delta}\right)
$$

where $F\left(I_{t} / \delta\right)$ is the value of the standard normal density distribution at $I_{t} / \delta$.

Estimation of $\beta$ and $\delta$ was accomplished through maximum likelihood, since the functional form is non-linear. The data was captured and checked in MS Excel 2007 and analyzed using Statistical Package for Social Scientists (SPSS V17). Statistically significant differences were declared at five percent level, unless stated otherwise.

\section{Results}

\subsection{Descriptive Statistics on Tree Retention Determinants}

3.1.1. Study Sites and Household Determinants of Tree Retention. The results showed study sites were significantly associated $(P<0.05)$ with the likelihood of the farmer willing to retain trees on farm (Table 2). Nyeri North district followed by Lari district had high significant proportion of farmers who were most likely to retain trees on farm as compared to those from Kikuyu and Nyeri South districts. Consequently, the study revealed significant associations $(P<0.05)$ between gender of the household head and farmers' decision to retain trees on farm. Male-headed households were most likely to retain trees on farm as compared to female-headed households.

Similarly, there were significant association $(P<0.05)$ between main occupation and farmers' willingness to retain trees. Farmers in formal full time employment had high proportion of tree retention as compared to full time farmers. Education was also a significant factor associated $(P<0.05)$ with farmers' decision to retain trees on farm. Of those attained post secondary and primary education had high proportion as compared to those who had no academic qualification. This was in contrast with marital status, which was not significantly associated $(P>0.05)$ with farmers decision to plant and retain trees on farm (Table 2).

Consequently, of the sampled farmers, 59, 31, and 10 per cent owned their land through inheritance from their parents, purchase, and given by the community/government, respectively. However, no significant associations were found between type of land ownership and farmers' decision to retain trees (Table 2). Land size significantly influenced $(P<$ $0.05)$ farmers' likelihood of tree retention. Farmers with average land size of 4.7 ha were most likely to retain trees as compared to those with 1.6 ha who were less likely. Farmers with an average land size of 1 ha were not likely to retain more trees on their farm. The study also revealed that exotic tree species were most preferred as compared to indigenous ones. In particular, eucalypts, Cupressus lusitanica and Grevillea robusta, were the most planted exotic species whereas the indigenous were dominated by Olea africana followed by Prunus africana and Croton megalocarpus. Subsequently, farmers who were motivated in tree planting for environmental conservation and improving sources of livelihood were mostly likely to plant and retain trees on farm.

\subsubsection{Tree Management and Marketability Determinants.} The study revealed 84 per cent of farmers interviewed lacked any technical skills in tree management as compared to 16 per cent who had acquired such skills. The specific skills were nursery establishment, thinning, pollarding, short rotation coppice, fertilizer application, tree harvesting, forest economics, and management of tree competition with agricultural crops among others. The acquisition of the technical skills was significantly associated $(P<0.05)$ with farmers' decision to retain trees on farm. Sixty six per cent of farmers with the technical skills were most likely to retain trees on farm as compared to those who had not obtained the same skills (Table 3). Similarly, the results showed that 94 per cent of the farmers did not receive forest extension services as compared to 6 per cent who received such services. The latter were most likely to retain trees on farm.

Farmers who sought authority from Kenya Forestry Service (KFS) to harvest their trees were significantly associated $(P<0.05)$ with the likelihood of tree retention on farm. In addition, farmers who found such regulations necessary on tree farming were most likely to plant and retain trees on their farms. The results also showed that 74 percent of the farmers viewed labour involved on tree management less intense. This significantly influenced their decision to plant and retain trees on farm for various uses (Table 3). Comparatively, no significant association was found between existence of village forest association and level of likelihood of farmers planting and retaining trees. Similarly, there was no significant association found between marketing problems and farmer's likelihood of tree planting and retention on farm (Table 3).

3.2. Correlation Analysis among Determinants for Tree Retention. The results also showed a positive significant correlation $(P<0.05)$ between major occupation and monthly 
TABLE 2: Study sites, household, and land ownership determinants associated with likelihood of farmers' tree retention in Central Kenya.

\begin{tabular}{|c|c|c|c|c|c|c|c|c|}
\hline \multirow[b]{2}{*}{ Determinants } & \multirow[b]{2}{*}{ Categories } & \multicolumn{3}{|c|}{$J=3$} & \multicolumn{4}{|c|}{$J=2$} \\
\hline & & $\begin{array}{c}\text { Not likely } \\
\%\end{array}$ & $\begin{array}{c}\text { Less likely } \\
\quad \% z\end{array}$ & $\begin{array}{c}\text { Most likely } \\
\%\end{array}$ & Total $(n)$ & $\begin{array}{c}\text { Not likely } \\
\%\end{array}$ & $\begin{array}{c}\text { Likely } \\
\%\end{array}$ & Total $(n)$ \\
\hline \multirow{4}{*}{ Site } & Kiambu-Lari & 19 & 35 & 46 & 48 & 46 & 54 & 48 \\
\hline & Kiambu-Kikuyu & 38 & 21 & 41 & 34 & 59 & 41 & 34 \\
\hline & Nyeri-South & 32 & 27 & 40 & 47 & 60 & 40 & 47 \\
\hline & Nyeri North & 15 & 23 & 62 & 79 & 38 & 62 & 79 \\
\hline \multirow{2}{*}{ Gender } & Male & 19 & 28 & 53 & 161 & 47 & 53 & 161 \\
\hline & Female & 39 & 21 & 40 & 199 & 61 & 40 & 38 \\
\hline \multirow{2}{*}{ Main occupation } & Full time farmer & 25 & 28 & 47 & 174 & 53 & 47 & 174 \\
\hline & Formal job & 15 & 19 & 68 & 14 & 33 & 68 & 27 \\
\hline \multirow{4}{*}{ Education level } & None & 30 & 35 & 35 & 23 & 65 & 35 & 23 \\
\hline & Primary & 22 & 24 & 54 & 79 & 46 & 54 & 79 \\
\hline & Secondary & 22 & 32 & 46 & 69 & 54 & 46 & 69 \\
\hline & Post secondary & 18 & 11 & 71 & 28 & 29 & 71 & 28 \\
\hline \multirow{3}{*}{ Marital status } & Married & 22 & 26 & 52 & 187 & 48 & 52 & 187 \\
\hline & Not married & 40 & 20 & 40 & 15 & 61 & 40 & 15 \\
\hline & Inherited & 21 & 30 & 49 & 120 & 51 & 49 & 120 \\
\hline \multirow[t]{2}{*}{ Land ownership } & Bought & 28 & 17 & 55 & 60 & 45 & 55 & 60 \\
\hline & Donated & 30 & 20 & 50 & 20 & 50 & 50 & 20 \\
\hline
\end{tabular}

TABLE 3: Tree management and marketability determinants of influencing farmer's tree retention on farm in Central Kenya.

\begin{tabular}{|c|c|c|c|c|c|c|c|c|}
\hline \multirow[b]{2}{*}{ Determinants } & \multirow[b]{2}{*}{ Categories } & \multicolumn{3}{|c|}{$j=3$} & \multicolumn{4}{|c|}{$j=2$} \\
\hline & & $\begin{array}{c}\text { Not likely } \\
\%\end{array}$ & $\begin{array}{c}\text { Less likely } \\
\%\end{array}$ & $\begin{array}{c}\text { Most likely } \\
\%\end{array}$ & Total $(n)$ & $\begin{array}{c}\text { Not likely } \\
\%\end{array}$ & $\begin{array}{c}\text { Likely } \\
\%\end{array}$ & Total $(n)$ \\
\hline \multirow{2}{*}{ Technical skills } & Yes & 14 & 21 & 66 & 29 & 34 & 66 & 29 \\
\hline & No & 26 & 28 & 46 & 163 & 54 & 46 & 163 \\
\hline \multirow{2}{*}{ Use of skills } & Yes & 14 & 7 & 79 & 28 & 21 & 79 & 28 \\
\hline & No & 26 & 19 & 55 & 31 & 45 & 55 & 31 \\
\hline \multirow{2}{*}{ Labour and cost } & Yes & 9 & 28 & 63 & 43 & 37 & 63 & 43 \\
\hline & No & 30 & 24 & 46 & 127 & 54 & 46 & 127 \\
\hline \multirow{2}{*}{ Extension services } & Yes & 0 & 22 & 79 & 9 & 22 & 78 & 9 \\
\hline & No & 25 & 27 & 48 & 183 & 52 & 48 & 183 \\
\hline \multirow{2}{*}{ Harvesting permission } & Yes & 18 & 26 & 57 & 97 & 43 & 57 & 97 \\
\hline & No & 32 & 27 & 41 & 71 & 59 & 41 & 71 \\
\hline \multirow{2}{*}{ Harvesting regulation } & Yes & 16 & 29 & 55 & 76 & 45 & 55 & 76 \\
\hline & No & 35 & 20 & 45 & 75 & 55 & 45 & 75 \\
\hline \multirow{2}{*}{ Village forest associations } & Yes & 16 & 35 & 49 & 57 & 51 & 49 & 57 \\
\hline & No & 27 & 22 & 51 & 112 & 49 & 51 & 112 \\
\hline \multirow{2}{*}{ Membership } & Yes & 23 & 31 & 46 & 35 & 54 & 46 & 35 \\
\hline & No & 25 & 26 & 49 & 148 & 51 & 49 & 148 \\
\hline \multirow{2}{*}{ Ready market } & Yes & 21 & 25 & 54 & 109 & 46 & 54 & 109 \\
\hline & No & 36 & 21 & 42 & 33 & 58 & 42 & 33 \\
\hline \multirow{2}{*}{ Marketing problems } & Yes & 10 & 29 & 61 & 31 & 39 & 61 & 31 \\
\hline & No & 28 & 25 & 47 & 117 & 53 & 47 & 117 \\
\hline
\end{tabular}

income as well as education level. There was a positive significant correlation $(P<0.05)$ between gender of the household head and major occupation. On the other hand, there was negative significant correlation $(P<0.05)$ between marital status and size of household as well as age of the household respondent (Table 4).
Consequently, there was a positive significant correlation $(P<0.05)$ between technical skills farmers gained in tree management and use of such skills in influencing them in tree growing and harvesting. The skills were equally highly correlated $(P<0.05)$ with harvesting regulation, which farmers found to be necessary and useful in motivating 
TABLE 4: Correlations among various demographic variables of tree retention.

\begin{tabular}{|c|c|c|c|c|c|c|c|}
\hline $\begin{array}{l}\text { Demographic } \\
\text { variables }\end{array}$ & $\begin{array}{l}\text { Gender of household } \\
\text { head }\end{array}$ & Marital status & $\begin{array}{c}\text { Major } \\
\text { occupation } \\
\end{array}$ & Household size & $\begin{array}{l}\text { Monthly } \\
\text { income }\end{array}$ & Age (yrs) & Education \\
\hline \multirow{2}{*}{$\begin{array}{l}\text { Gender of } \\
\text { household head }\end{array}$} & 1.000 & 0.247 & -0.125 & -0.038 & -0.048 & 0.063 & -0.098 \\
\hline & & $P=0.001$ & $P=0.064$ & $P=0.324$ & $P=0.281$ & $P=0.224$ & $P=0.118$ \\
\hline \multirow{2}{*}{ Marital status } & & 1.000 & -0.032 & -0.165 & -0.041 & -0.227 & 0.070 \\
\hline & & & $P=0.351$ & $P=0.022$ & $P=0.310$ & $P=0.003$ & $P=0.197$ \\
\hline \multirow{2}{*}{ Major occupation } & & & 1.000 & -0.108 & 0.240 & -0.029 & 0.374 \\
\hline & & & & $P=0.094$ & $P=0.002$ & $P=0.361$ & $P=0.000$ \\
\hline \multirow{2}{*}{$\begin{array}{l}\text { Number of } \\
\text { members } \\
\text { household }\end{array}$} & & & & 1.000 & 0.035 & 0.063 & -0.169 \\
\hline & & & & & $P=0.335$ & $P=0.449$ & $P=0.019$ \\
\hline \multirow{2}{*}{ Monthly income } & & & & & 1.000 & 0.011 & 0.179 \\
\hline & & & & & & $P=0.449$ & $P=0.014$ \\
\hline \multirow{2}{*}{ Age in years } & & & & & & 1.000 & -0.452 \\
\hline & & & & & & & $P=0.000$ \\
\hline Education & & & & & & & 1.000 \\
\hline
\end{tabular}

* Probability value ( $P$ value).

TABLE 5: Correlation matrix among the farm determinants of tree retention.

\begin{tabular}{|c|c|c|c|c|c|c|}
\hline & Technical skills & Use of skills & Labour cost & $\begin{array}{l}\text { Extension } \\
\text { services }\end{array}$ & $\begin{array}{l}\text { Harvesting } \\
\text { permission }\end{array}$ & $\begin{array}{c}\text { Harvesting regulation } \\
\text { and tree farming }\end{array}$ \\
\hline \multirow{2}{*}{ Technical skills } & 1.000 & 0.819 & -0.024 & 0.275 & 0.152 & 0.483 \\
\hline & & $P=0.00$ & $P=0.434$ & $P=0.025$ & $P=0.144$ & $P=0.000$ \\
\hline \multirow{2}{*}{ Use of skills } & & 1.00 & 0.013 & 0.204 & 0.145 & 0.372 \\
\hline & & & $P=0.463$ & $P=0.075$ & $P=0.155$ & $P=0.004$ \\
\hline \multirow{2}{*}{ Labour and cost } & & & 1.000 & -0.081 & -0.063 & -0.188 \\
\hline & & & & $P=0.286$ & $P=0.331$ & $P=0.093$ \\
\hline \multirow{2}{*}{ Extension services } & & & & 1.000 & 0.130 & 0.231 \\
\hline & & & & & $P=0.182$ & $P=0.051$ \\
\hline \multirow{2}{*}{ Harvesting permission } & & & & & 1.000 & 0.244 \\
\hline & & & & & & $P=0.042$ \\
\hline $\begin{array}{l}\text { Harvesting regulation and } \\
\text { tree farming }\end{array}$ & & & & & & 1.000 \\
\hline
\end{tabular}

* Probability value ( $P$ value).

their decision for tree farming. Similarly, the technical skills obtained on tree farming by farmers were significantly correlated $(P<0.05)$ with extension services received on tree management. This was consistent with the use of skills gained in tree farming. Seeking permission from Kenya Forestry Service to harvest trees was significantly correlated $(P<0.05)$ with level of acceptance on such regulations. This was found to be necessary and useful in motivating the farmers to participate in tree farming (Table 5). The extension services were also positively and significantly correlated $(P=0.015)$ with motivation to plant trees for environmental conservation and source of livelihood.

There was also a significant positive correlation ( $\rho=$ $0.570 ; P=0.000$ ) between existence of village forest village association and membership of the farmers. Similarly, there was significant correlation $(\rho=0.491 ; P=0.002$ ) between village forest membership and ready market of forest products. In addition, there was a significant positive correlation ( $\rho=0.175, P=0.001)$ between land size and monthly income as well as land size and age ( $\rho=0.18, P=$ 0.013 ). In addition, there was a significant correlation ( $\rho=$ $0.213, P=0.000$ ) between land size and the number of trees planted on farm. There was also positive significant correlation ( $\rho=0.217, P=0.008$ ) between acquisition of technical skills and marketability of tree produce.

3.3. Determinants of Tree Retention Using Multinomial and Binary Logistic Regression Models. Both binary and multinomial logistic regression following stepwise method of fitting variables showed gender, age, major occupation, education level, monthly income, land size, extension services, site, motivational reasons of tree planting, labour, acquisition of technical skills, cost involved in tree management, harvesting 
TABLE 6: Likelihood ratio tests and model classification of tree retention determinants using binary and multinomial logistic regression.

\begin{tabular}{|c|c|c|c|c|c|c|c|c|}
\hline \multirow{2}{*}{ Determinants } & \multicolumn{2}{|c|}{$-2 \log$ likelihood } & \multicolumn{2}{|c|}{ d.f } & \multicolumn{2}{|c|}{$P$ value } & \multicolumn{2}{|c|}{ \% Model classification } \\
\hline & ${ }^{*} \log t$ & ${ }^{*}$ Mult & Logistic & Multinomial & Logistic & Multinomial & Logistic & Multinomial \\
\hline Site & 281 & 45.1 & 3 & 6 & 0.05 & 0.04 & 59 & 50 \\
\hline Gender $\mathrm{HH}^{*}$ & 273 & 24.8 & 1 & 2 & 0.12 & 0.03 & 55 & 51 \\
\hline Occupation & 275 & 20.6 & 1 & 2 & 0.06 & 0.16 & 55 & 50 \\
\hline Age & 262 & 238 & 1 & 126 & 0.93 & 0.06 & 52 & 67 \\
\hline Education & 267 & 40.0 & 3 & 6 & 0.04 & 0.14 & 58 & 52 \\
\hline Marital status & 279 & 18.7 & 1 & 2 & 0.38 & 0.32 & 53 & 51 \\
\hline $\mathrm{NMH}^{*}$ & 275 & 85 & 1 & 2 & 0.47 & 0.47 & 53 & 52 \\
\hline Income & 220 & 168 & 1 & 80 & 0.00 & 0.00 & 60 & 53 \\
\hline Land tenure & 276 & 43.9 & 2 & 10 & 0.76 & 0.15 & 52 & 51 \\
\hline Land size & 231 & 130 & 1 & 6 & 0.00 & 0.00 & 68 & 68 \\
\hline Tree use & 240 & 27.3 & 2 & 4 & 0.35 & 0.53 & 55 & 48 \\
\hline Motivation & 225 & 27.5 & 1 & 2 & 0.20 & 0.01 & 56 & 52 \\
\hline Technical skills & 262 & 21.1 & 1 & 2 & 0.05 & 0.13 & 56 & 49 \\
\hline Skill effect & 71.8 & 16.6 & 1 & 2 & 0.05 & 0.14 & 66 & 66 \\
\hline Labour and cost & 232 & 25.8 & 1 & 2 & 0.05 & 0.01 & 57 & 50 \\
\hline Extension services & 263 & 18.8 & 1 & 2 & 0.07 & 0.06 & 53 & 50 \\
\hline Harvest permission & 229 & 23.9 & 1 & 2 & 0.04 & 0.05 & 58 & 50 \\
\hline Harvesting regulation & 208 & 25 & 1 & 2 & 0.22 & 0.02 & 55 & 50 \\
\hline Forest associations & 234 & 22.1 & 1 & 2 & 0.83 & 0.11 & 51 & 50 \\
\hline Membership & 253 & 18.1 & 1 & 2 & 0.70 & 0.79 & 51 & 49 \\
\hline Ready market & 195 & 19.8 & 1 & 2 & 0.24 & 0.22 & 55 & 51 \\
\hline Marketing problems & 203 & 21.7 & 1 & 2 & 0.16 & 0.07 & 55 & 50 \\
\hline
\end{tabular}

* Logt: Logistic regression values; ${ }^{*}$ Mult: multinomial logistic regression values; $\mathrm{HH}^{*}$ : household head; $\mathrm{NMH}^{*}$ : number of members in the household.

permission from KFS and existence of forest associations as significant determinants influenced the likelihood of the farmer willing to plant and retain trees on farm (Table 6).

Farmers with higher monthly income and large land size had high chance of planting and retaining trees on farm. Specifically, increase of income had a unit increase in tree planting and retention. Similarly, unit increase of land resulted to about 1.4 times chances higher of farmers' decision to plant and retains trees. The computed predicted probabilities on monthly income and land size of the farmers showed that as monthly income increased and land size, there was corresponding increase of probability of the farmers planting and retaining trees on farm with $100 \%$ model prediction (Figures 3 and 4 ).

The odds of farmers from Nyeri North district likely to retain trees on farm as compared to those from Nyeri South, Kikuyu, and Lari were 60, 60, and 50 per cent higher, respectively (Table 7). Similarly, farmers from Nyeri North district had significantly high logits of most likely to retain trees on farm as compared to Kikuyu and Nyeri South farmers.

However, there were no significant differences $(P>0.05)$ on the logits of the farmers who were not likely to retain trees on farm from Nyeri North as compared to those from Nyeri South and Lari districts (Table 7).

Farmers on full time formal employment had 50 per cent higher logits of tree planting and retention as compared to full time farmers. In addition, farmers with postsecondary

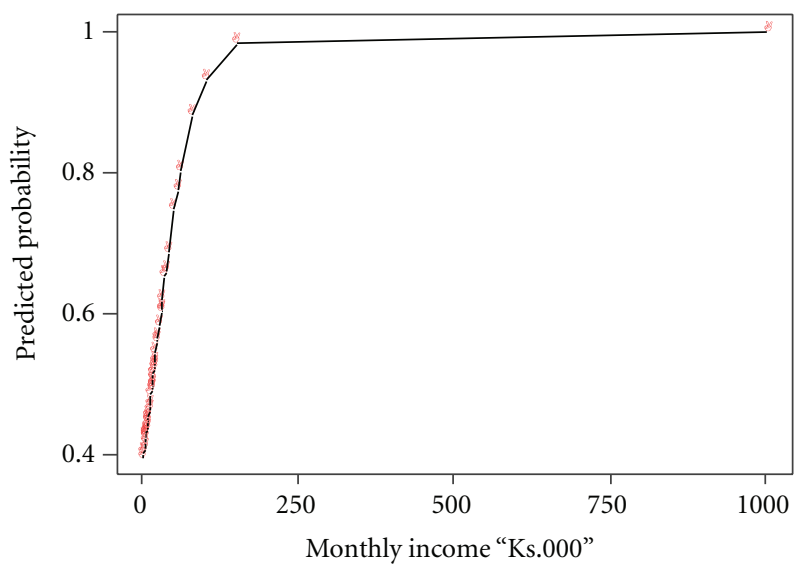

Figure 3: Monthly income (Kenya Shilling) and predicted probability of the farmers tree planting and retention on farm in Central Kenya.

education had about 80,50 , and 70 per cent chances higher of planting and retaining trees on farm as compared to those with formal primary and secondary education, respectively. Furthermore, the logits of the male-headed households most likely and less likely to retain trees on farm were about 2.9 and 2.8 times significantly higher as compared to female-headed households not likely to plant and retain trees (Table 8). 
TABLE 7: Binary logistic regression model on fitting determinants of farmer's tree retention on farm in Central Kenya.

\begin{tabular}{|c|c|c|c|c|c|c|}
\hline Determinants & Categories & Reference category & $\beta$ & S.e $(\beta)$. & Odds ratio & $P$ value \\
\hline \multirow{3}{*}{ Site } & Kiambu-Lari & Nyeri North & -0.66 & 0.37 & 0.5 & 0.076 \\
\hline & Kiambu-Kikuyu & & -0.85 & 0.42 & 0.4 & 0.043 \\
\hline & Nyeri South & & -0.88 & 0.38 & 0.4 & 0.020 \\
\hline Gender & Male & Female & 0.56 & 0.37 & 1.8 & 0.125 \\
\hline Household members & - & - & 0.04 & 0.05 & 1.8 & 0.477 \\
\hline Monthly income & - & - & 0.00 & 0.00 & 1 & 0.004 \\
\hline Land size & - & - & 0.36 & 0.07 & 1.4 & 0.000 \\
\hline Marital status & Single & Married & 0.48 & 0.55 & 1.6 & 0.380 \\
\hline Major occupation & Formal job & Full time farmer & -0.81 & 0.44 & 0.5 & 0.064 \\
\hline \multirow{3}{*}{ Education } & None & Post secondary & -1.55 & 0.61 & 0.2 & 0.011 \\
\hline & Primary & & -0.74 & 0.48 & 0.5 & 0.120 \\
\hline & Secondary & & -1.06 & 0.48 & 0.3 & 0.028 \\
\hline Age & - & - & 0.001 & 0.01 & 1.0 & 0.927 \\
\hline \multirow{2}{*}{ Tree use } & Fuel wood & \multirow{2}{*}{ Aesthetic } & -0.55 & 0.47 & 0.6 & 0.243 \\
\hline & Timber & & -0.16 & 0.49 & 0.8 & 0.533 \\
\hline Tree Motivation & Conserve environment & Source of livelihood & 0.420 & 0.330 & 1.5 & 0.203 \\
\hline Technical skills & Obtained technical skills & Did not obtain skills & 0.802 & 0.421 & 2.2 & 0.057 \\
\hline Effect of skills & Skills were useful & Skills not useful & 1.105 & 0.585 & 3.0 & 0.059 \\
\hline Labour and cost & Intensive & Not intensive & 0.697 & 0.362 & 2.0 & 0.054 \\
\hline Extension services & Received extension services & Did not receive extension services & 1.329 & 0.815 & 3.8 & 0.103 \\
\hline Harvesting permission & Sought harvesting permission & Did not seek permission & 0.640 & 0.317 & 1.9 & 0.043 \\
\hline Harvesting regulation & Harvesting regulation important & Harvesting regulation not important & 0.399 & 0.327 & 1.5 & 0.223 \\
\hline Forest associations & Existence of forest associations & No existence of forest association & -0.071 & 0.325 & 0.9 & 0.828 \\
\hline Membership & Member of forest association & Not a member & -0.145 & 0.377 & 0.9 & 0.701 \\
\hline Ready market & Ready market access & No ready market access & 0.471 & 0.401 & 1.6 & 0.241 \\
\hline Marketing problems & Existence of marketing problems & No marketing problems & 0.579 & 0.413 & 1.8 & 0.160 \\
\hline
\end{tabular}

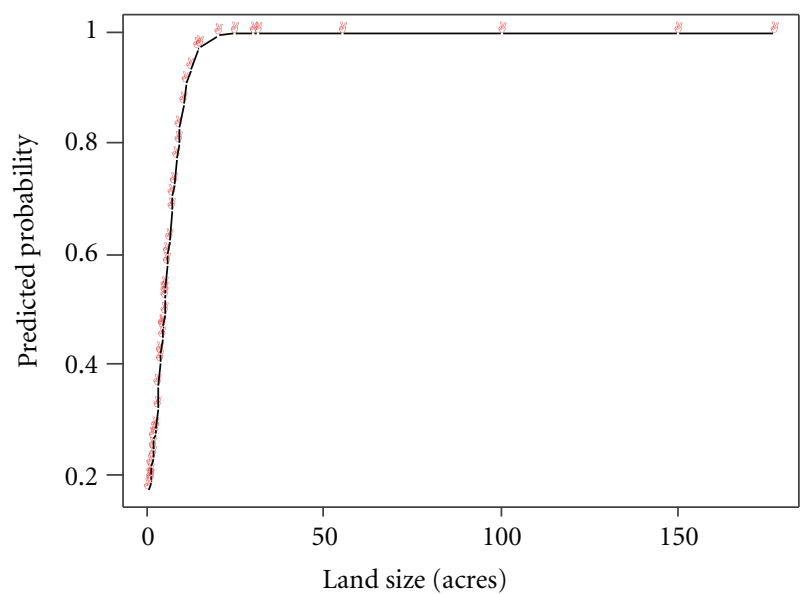

FIGURE 4: Land size and predicted probability of the farmers' tree planting and retention on farm in Central Kenya.

Farmers with technical skills had about 2.2 times chances higher of planting and retaining trees than those who had not acquired similar skills. Moreover, farmers who did not view labour involved in tree management as intense and costly had about two times chances higher of tree planting and retention as compared to who viewed tree farming as labour intense and costly. The chances of farmers who sought permission from KFS to harvest their trees were about 2.6 times higher to plant and retain trees (Table 8). Farmers motivated to plant trees for environmental conservation as compared to those for source of livelihood were about 3.5 times most likely to retain trees on farm as compared to those who were not likely. Similarly, farmers not experienced any marketing problems of tree produce had about 3.8 times chances higher of most likely to plant and retain trees on farm as compared to unlikely ones (Table 8). Overall, logistic regression model provided better prediction of uncorrelated determinants of tree planting and retention as compared to multinomial logistic regression model. The binary logic regression model correctly predicted $82 \%$ and $81 \%$ not likely and likely to plant and retains trees, respectively. This resulted to $81 \%$ of the overall prediction of determinants influencing tree planting and retention (Table 8).

\section{Discussion}

The significant effect of site in influencing farmers' decision to plant and retain trees on farm underscored the importance 
TABLE 8: Multinomial logistic regression model on fitting determinants of farmer's tree retention on farm in Central Kenya.

\begin{tabular}{|c|c|c|c|c|c|c|c|c|}
\hline \multirow{2}{*}{ Explanatory variable } & \multicolumn{4}{|c|}{ Most likely/not likely } & \multicolumn{4}{|c|}{ Less likely/not likely } \\
\hline & $\beta$ & S.e $(\beta)$. & $P$ value & Odds ratio & $\beta$ & S.e $(\beta)$. & $P$ value & Odds ratio \\
\hline Intercept & 1.41 & 0.32 & - & - & 0.41 & 0.37 & - & - \\
\hline \multicolumn{9}{|l|}{ Site } \\
\hline Lari & -0.51 & 0.51 & 0.315 & 0.6 & 0.23 & 0.56 & 0.678 & 1.3 \\
\hline Kikuyu & -1.33 & 0.50 & 0.008 & 0.3 & -1.03 & 0.60 & 0.087 & 0.4 \\
\hline Nyeri South & -1.17 & 0.47 & 0.013 & 0.3 & -0.55 & 0.53 & 0.302 & 0.6 \\
\hline Gender & 1.05 & 0.42 & 0.013 & 2.9 & 1.03 & 0.50 & 0.038 & 2.8 \\
\hline Intercept & 0.00 & 0.37 & & & -0.63 & 0.44 & & \\
\hline \multicolumn{9}{|l|}{ Education } \\
\hline None & -1.25 & 0.72 & 0.082 & 0.3 & 0.64 & 0.90 & 0.472 & 1.9 \\
\hline Primary & -0.46 & 0.58 & 0.426 & 0.6 & 0.62 & 0.80 & 0.439 & 1.9 \\
\hline Secondary & -0.63 & 0.59 & 0.287 & 0.5 & 0.89 & 0.80 & 0.266 & 2.4 \\
\hline Intercept & 1.39 & 0.50 & & & -0.511 & 0.73 & & \\
\hline Motivation & 1.24 & 0.44 & 0.005 & 3.5 & 1.40 & 0.49 & 0.005 & 4.0 \\
\hline Intercept & 0.37 & 0.31 & & & & & & \\
\hline Labour and cost & 1.49 & 0.58 & 0.010 & 4.4 & 1.30 & 0.63 & 0.038 & 3.7 \\
\hline Intercept & 0.42 & 0.21 & & & -0.20 & 0.24 & & \\
\hline Harvesting permission & 0.94 & 0.39 & 0.017 & 2.6 & 0.58 & 0.44 & 0.191 & 1.8 \\
\hline Intercept & 0.23 & 0.28 & & & -0.19 & 0.31 & & \\
\hline Harvesting regulation & 0.98 & 0.42 & 0.019 & 2.7 & 1.16 & 0.48 & 0.017 & 3.2 \\
\hline Intercept & 0.27 & 0.26 & & & -0.55 & 0.32 & & \\
\hline Marketing problem & 1.33 & 0.66 & 0.043 & 3.8 & 1.23 & 0.71 & 0.085 & 3.4 \\
\hline Intercept & 0.51 & 0.22 & & & -0.13 & 0.26 & & \\
\hline Forest association & 0.49 & 0.445 & 0.267 & 1.6 & 0.98 & 0.48 & 0.043 & 2.7 \\
\hline Intercept & 0.64 & 0.27 & & & -0.18 & 0.27 & & \\
\hline
\end{tabular}

of taking into account the uniqueness of each geographical location. This is because sites vary in climatic conditions and other characteristics that are likely to have a great influence in tree planting and retention. In this study the four selected sites were very distinct in amount of rainfall, soils, population density, and proximity to other geographical features/major towns among others. For instance, Nyeri North district had large land sizes, which may explain high level of tree planting and retention as compared to other three districts. This corroborates with other studies that have shown land is a significant factor influencing community's decision to plant trees on large scale. One percent increase in land under outright ownership, there was a 7.6 per cent in the probability that farmers will establish forest plantations. Farmers with small-scale land holdings opted for agricultural rather than forest plantations, as they needed immediate cash flow hence shorter rotations of crops cultivated [17, 18]. The proximity of Nyeri North district to the slopes of Mt. Kenya and surrounding of forest plantations may have as well induced farmers into the culture of tree planting. This might be a result of strict regulation imposed by the Government of the Republic of Kenya in accessing forest products from government owned and managed forests. The inhabitants therefore around this region were more likely to shift in establishing their own woodlots/plantations or tree boundary planting in meeting their household wood energy and other forest products needs. Also, with imposed ban on tree harvesting from government forest plantations, availability of forest products such as timber, transmission poles, construction posts, and many others were likely to be limited in supply. The prices of such products were virtually on increase due to high demand. This may have triggered farmers with large land sizes to venture into tree farming with an aim of capitalizing existing market. During the data collection around this region, it was evident that farmers with large land sizes had widely invested in tree planting.

The low levels of likelihood of farmers to plant and retain trees at Nyeri South and Kikuyu districts may be attributed to small land holdings due to high population. The nature of their farming activities were dairy, tea growing and subsistence crops. This may have delineated them from active participation in tree farming as most of the land was needed for pasture and food crops. This was in contrast with Nyeri North district where the concept of planting alone was not adequate to advance forest cover but the interest to keep trees on farm will significantly contribute to forest cover. For instance, the discussions held with farmers during data collection in this region pointed out that majority of them viewed tree growing as a long-term investment with no immediate cash to offset household needs, hence lowly prioritized. Therefore, chances of finding more trees on farm of varied sizes were small reflecting less retention. In cases where farmers had trees on their farms, the site was less productive and sometimes with deep gradient which was 
not suitable for agricultural farming. This demonstrated that such group of farmers least valued trees in their fertile lands as compared to food crops hence a motivation of continuous tree planting and retention so long as the site of the land remained unproductive. This was further evidenced by farmers in the drier area of Kikuyu district engaged more in tree planting due to less land productivity and less rainfall for agricultural crops. In this case there was high likelihood that such farmers would continue planting and keeping trees on their farm to meet various household needs unless better alternatives of land uses for drier areas were availed. This corroborates with findings of other studies where farmer-owned woodlands were reported to generally occur along rivers and streams which were too hilly or rocky for row crops [6]. Landowners who had higher percentage of land in crops were considerably less likely to express interest in agroforestry suggesting that row crops and trees were incompatible [5]. Overall, location factors have been found among key determinants influencing variationsonthe likelihood of managing natural resources including trees on farm and engagement in forest management [19].

The significant contribution of male headed household in the likelihood of tree planting and retention as compared to female headed households may be explained by cultural setting of the community members of the study sites. Women might have limited access to landownership, participation in community groups as a result of household duties among others resulting to less interest in tree farming. Similar differentials were reported by [20-22]. Social cultural norms and traditions define and shape behaviour of men and women, which present obstacles to participation in resource management effort. Men are considered to be responsible for village development and governance, reducing women to their personal and household attributes, which continue to constrain them. However women's participation in community forest management has been enhanced by roles of various institutions, which changed the assumption that men were more actively involved in forest management than women [22].

The major occupation of farmers particularly, those in formal employment were leveraged in tree planting and retention. These groups of farmers in formal employment were not necessarily depending on their land for their livelihoods hence may give environmental, aesthetic and recreational factors more weight than financial ones when making land use decisions. This resulted to high likelihood of tree planting and retention corroborating well with the findings of [5]. Similarly, studies have shown that those who had off time employment opportunities, access to credit and total household income may be associated with reduced tree felling on farm leading to high probability of tree retention. Consequently, farmers who derive significant income from their trees and viewed their forests as source to be tapped periodically for income would engage in practices that would maintain or enhance income regenerating opportunities $[6$, 23].

Education plays a significant role in understanding the need to conserve the environment through various practices. During the learning period individuals acquire relevant knowledge, skills, and values appropriate for sustainable farm forestry. This was evident on this study where farmers with secondary school and post secondary education qualifications were most likely to plant and retain trees. Knowledge in agroforestry has been found to significantly correlate with level of education where college graduates tended to be more interested in agroforestry than their counterparts with less academic qualifications. Every additional year of education decreased the probability that the household exploited forest/tree products and less conversion of woodlands to arable land $[5,9,10,19,24]$. The acquisition of technical skills improved techniques of the farmers on silvicultural tree management and created awareness on the role of trees on farm and for environmental conservation. The positive correlation between technical skills and extensions services implied that majority of the farmers had not obtained knowledge on tree management. Access to and use of extension services has a positive impact on silvicultural investment by farmers who had established plantations. Forest owners who had attended forestry extension activities were 2.6 times more likely to have decided to thin their stands than those that had not $[17,25,26]$.

Middle aged and young farmers were planting trees on their farm with an aim of generating income and household needs like supply of fuelwood, timber, construction poles, and boundary marking of their lands from neighbours. This tended to influence the probability of likelihood of tree planting and retention. For instance, with population increase, there will be always demand for wood products indicating ready market that is likely to stimulate tree planting and retention for future direct and indirect needs. This concurs with a study carried on farmer participatory evaluation of agroforestry trees in eastern Zambia which showed that fuelwood and construction materials were most important and second most important by-products among the group of farmers likely to have influenced tree growing [27]. Nevertheless, some studies have shown that young households contemplated on forest farming as an income activity whereas older people possesses superior knowledge about various forest resources, more likely to participate in forestry programs and may utilize more medicinal plants and wild foods resulting to high retention of trees on farm $[4,16,22,24]$.

The significant contribution of village forest association on the likelihood of tree planting and retention implied that the roles undertaken by these groups such as: supply of seeds, seedling production, tree planting, thinning, pruning, bee keeping, environmental conservation, and marketing had a positive effect on farm forestry. Studies have shown that becoming a member of a farmers' group increased knowledge and farmers' participation in forestry activities $[17,18,24]$. This has been revitalized in Kenya through the new Forests Act No. 7 of 2005, which has formally recognized establishment of Community Forests Associations (CFAs) in all forests Conservancies. These groups have a national mandate in comanagement of forest resources with the government at grassroots level. Some of the activities they undertake include, community forests policing, tree planting, sustainable use of forest resources, trainings in 
nursery establishment, and marketing of forest products among others. Deriving such forest benefits will not only strengthen the associations but also change attitude on tree farming. This would cumulatively improve the forest/tree cover in the country through planting and conservation.

The reinforcement of forest regulation on tree harvesting by Government of Republic of Kenya through KFS significantly influenced the farmers to retain trees on farm and participate in tree growing. This was in contrast with what has been reported in the past where seeking permission to harvest trees, which the farmers had planted, would discourage them from continuous tree planting [28]. However, in this study farmers viewed such measures as important because harvesting trees without permission would not only affect the environment but also encourage theft in farmers' field and government forests. This was further evidenced by [29] who examined Ukrainian forest regulatory policy on forest groups and permit classifications that permit or prohibit final felling and found out that such instruments were directed towards maintaining the environment and social functions of specified forests.

\section{Policy Implication and Conclusion}

The household, farm attributes, tree management and marketability characteristics were instrumental determinants that influenced the farmer's decision on tree planting and retention. The findings of this study therefore would be crucial in assisting the government of Kenya to effectively address forestry and agriculture sector policy reforms geared towards improving forest cover to $10 \%$ in the next decade. One objective of such policy reforms would perhaps be enhancing capacity to monitor the land use management systems across the country. This would lead to identification and mapping of specific sites that would be useful in tree planting such as top hills, degraded areas not suitable for agricultural crops and fallow lands among others. Consequently, the forest policy would provide direction on evaluation of farm forestry needs in each of the specific locations of the country in strengthening the culture of tree planting. This is likely to direct the allocation of resources while greening the country. The role played by gender, age, and major occupation in tree planting and retention would guide activities of promoting specific forestry programmes in Kenya. For instance, it is important to match the type of tree to the needs of men and women and farmers of different ages.

The need for extension services requires more investment in human capital and facilities. This would dictate for allocation of more funds to recruit and equip the personnel with appropriate facilities to enable them undertake their extension services well. The revision of Sessional Paper No. 1 on Forest Policy which is currently underway and new farm forestry guidelines in the Agricultural Act (Cap 318) would need to take into account of these needs if 10 per cent forest cover in Kenya would become a reality. For example, it has been currently diagnosed that Kenya has a shortfall of over 3000 agricultural and forestry extension officers. This would significantly hinder evergreen agricultural services to the general public. The significant contribution of household income in tree planting and retention would as well shift the government policies on employment opportunities in order to reduce pressure on land and enhance tree planting. Equally, enhancing the level of literacy in the country would strengthen efforts of environmental conservation measures. Overall, the significant determinants found in this study influencing tree planting and retention would significantly help the country to develop appropriate technical working papers that will spearhead the success of farm forestry with an aim of improving forest cover in Kenya.

In conclusion, the approaches used in undertaking this study especially the application of binary and multinomial logistic regression model explicitly revealed the key determinants influenced farmers' decision to plant and retain trees on farm. Ideally tree planting alone is not sufficient to indicate that tree cover will be improved but an assessment of retention forms a critical point that needs to be assessed because in farm forestry farmers have out right ownership of land and management. They are likely to shift to different land uses other than tree growing. Accounting the contribution of various determinants to tree growing would lead to set of realistic objectives and strategies that would enable the country realize the dream of increasing tree/forest cover to 10 per cent.

\section{Acknowledgments}

The authors thank Kenya Forestry Research Institute Board of Managament and Director for allocating financial resources to undertake this study. They are especially grateful to farmers who were resourceful in providing useful data for this study. They are indebted to the enumerators James Mwaura, Monica Ndegwa, Ulysses Gitonga, George Okwaro, and Kimani Samuel for their effective data collection.

\section{References}

[1] World Agro-forestry Centre, "Creating an Evergreen Agriculture in Africa for food security and environmental resilience," Tech. Rep., World Agro-forestry Centre, Nairobi, Kenya, 2009.

[2] Teagasc Agriculture and Food Development Authority (TAFDA), "A road map for the Farm Forestry Sector to 2015," Tech. Rep., Teagasc Agriculture and Food Development Authority (TAFDA), Dublin, Ireland, 2007.

[3] I. Guijt and D. Race, Growing Successfully, Australian Experiences with Farm Forestry, Greening Australia, Canberra, Australia, 1998.

[4] C. Valdivia and C. Poulos, "Factors affecting farm operators' interest in incorporating riparian buffers and forest farming practices in northeast and southeast Missouri," Agroforestry Systems, vol. 75, no. 1, pp. 61-71, 2009.

[5] J. G. Arbuckle Jr., C. Valdivia, A. Raedeke, J. Green, and J. S. Rikoon, "Non-operator landowner interest in agroforestry practices in two Missouri watersheds," Agroforestry Systems, vol. 75, no. 1, pp. 73-82, 2009.

[6] W. K. Moser, E. C. Leatherberry, M. H. Hansen, and B. J. Butler, "Farmers' objectives toward their woodlands in the 
upper Midwest of the United States: implications for woodland volumes and diversity," Agroforestry Systems, vol. 75, no. 1, pp. 49-60, 2009.

[7] K. Konyar and C. T. Osborn, "A national-level economic analysis of Conservation Reserve Program participation: a discrete choice approach," Journal of Agricultural Economics Research, vol. 42, no. 2, pp. 5-12, 1990.

[8] K. Mahapatr and S. Kant, "Tropical deforestation: a multinomial logistic model and some country-specific policy prescriptions," Forest Policy and Economics, vol. 7, no. 1, pp. 1-24, 2005.

[9] F. Dolisca, J. M. McDaniel, L. D. Teeter, and C. M. Jolly, "Land tenure, population pressure, and deforestation in Haiti: the case of Forêt des Pins Reserve," Journal of Forest Economics, vol. 13, no. 4, pp. 277-289, 2007.

[10] P. Krishna, S. Murai, and Y. Yasuoka, "Sustainability analysis for human population in relation with global deforestation using remote sensing and GIS in international archives of photogrammetry and remote sensing," in Proceedings of 19th Congress of International Society for Photogrammetry and Remote Sensing, vol. 33, Part B3, pp. 800-804, Amsterdam, Netherlands, 2000.

[11] Kenya Forestry Research Institute, Kenya Forestry Research Institute Strategic Plan 2008-2012, Kenya Forestry Research Institute, Nairobi, Kenya, 2008.

[12] Government of the Republic of Kenya (a), Kenya Vision 2030 Sector Plan For Environment, Water and Sanitation 2008-2012, Government Printers, Nairobi, Kenya, 2008.

[13] D. Rocheleau and D. Edmunds, "Women, men and trees: gender, power and property in forest and agrarian landscapes," World Development, vol. 25, no. 8, pp. 1351-1371, 1997.

[14] S. J. Scherr, "Economic factors in farmer adoption of agroforestry: patterns observed in Western Kenya," World Development, vol. 23, no. 5, pp. 787-804, 1995.

[15] Government of the Republic of Kenya (b), The Constitution of Kenya, Laws of Kenya 2010, National Council for Law Reporting with the Authority of the Attorney General, 2010.

[16] J. Ralph, S. Helmut, H. Berthold, and S. Chris, Farm Management Handbook of: Natural Conditions and Farm Management Information, vol. 2, Part B. Central Kenya, Subpart B2. Central Province, Ministry of Agriculture, Nairobi, Kenya, 2nd edition, 2006.

[17] D. Zhang and E. Aboagye Owiredu, "Land tenure, market, and the establishment of forest plantations in Ghana," Forest Policy and Economics, vol. 9, no. 6, pp. 602-610, 2007.

[18] U. J. Siregar, A. Rachmi, M. Y. Massijaya, N. Ishibashi, and K. Ando, "Economic analysis of sengon (Paraserianthes falcataria) community forest plantation, a fast growing species in East Java, Indonesia," Forest Policy and Economics, vol. 9, no. 7, pp. 822-829, 2007.

[19] M. Völker and H. Waibel, "Do rural households extract more forest products in times of crisis? Evidence from the mountainous uplands of Vietnam," Forest Policy and Economics, vol. 12, no. 6, pp. 407-414, 2010.

[20] A. G. Adedayo, M. B. Oyun, and O. Kadeba, "Access of rural women to forest resources and its impact on rural household welfare in North Central Nigeria," Forest Policy and Economics, vol. 12, no. 6, pp. 439-450, 2010.

[21] R. K. Nuggehalli and L. S. Prokopy, "Motivating factors and facilitating conditions explaining women's participation in co-management of Sri Lankan forests," Forest Policy and Economics, vol. 11, no. 4, pp. 288-293, 2009.

[22] V. Maskey, T. G. Gebremedhin, and T. J. Dalton, "Social and cultural determinants of collective management of community forest in Nepal," Journal of Forest Economics, vol. 11, no. 4, pp. 261-274, 2006.

[23] G. Janse and A. Ottitsch, "Factors influencing the role of nonwood forest products and services," Forest Policy and Economics, vol. 7, no. 3, pp. 309-319, 2005.

[24] B. Odoemena, E. Eboh, P. Okoli et al., "Econometric analysis of the micro-level determinants of woodland conversion to arable cropping and implications to policy in Eastern Nigeria," African Journal of Agricultural Research, vol. 5, no. 11, pp. 1168-1178, 2010.

[25] A. N. Dhubháin, K. Maguire, and N. Farrelly, "The harvesting behaviour of Irish private forest owners," Forest Policy and Economics, vol. 12, no. 7, pp. 513-517, 2010.

[26] V. Rodríguez-Vicente and M. F. Marey-Pérez, "Land-use and land-base patterns in non-industrial private forests: factors affecting forest management in Northern Spain," Forest Policy and Economics, vol. 11, no. 7, pp. 475-490, 2009.

[27] E. Kuntashula and P. L. Mafongoya, "Farmer participatory evaluation of agroforestry trees in eastern Zambia," Agricultural Systems, vol. 84, no. 1, pp. 39-53, 2005.

[28] K. J. Githiomi, Micro level wood energy planning for Kiambu, Thika and Maragwa districts. A case study of decentralized energy plan in Kenya [Ph.D. thesis], Kenyatta University, Nairobi, Kenya, 2010.

[29] M. Polyakov and L. Teeter, "The influence of regulatory forest policy tools on biodiversity measures for forests in Ukraine," Forest Policy and Economics, vol. 7, no. 6, pp. 848-856, 2005. 

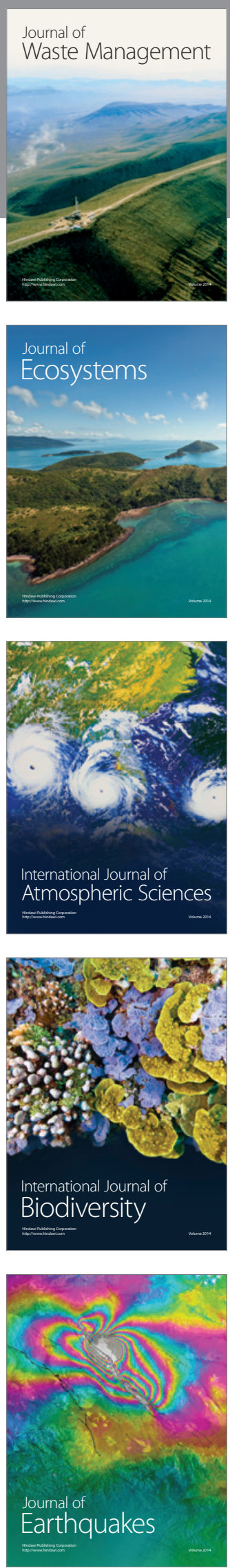
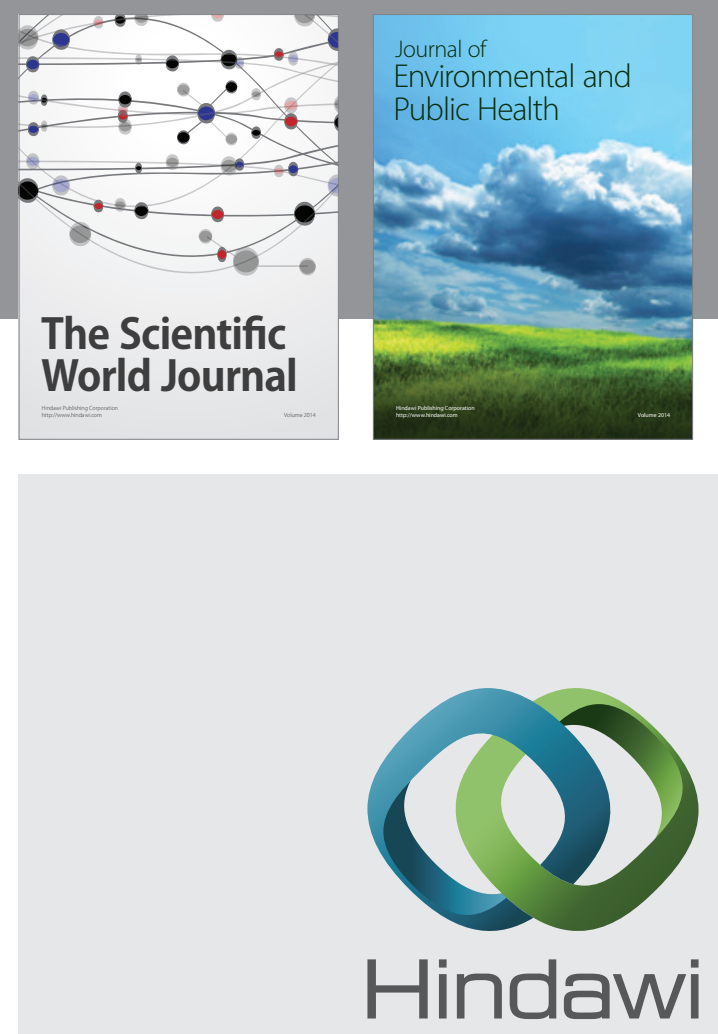

Submit your manuscripts at

http://www.hindawi.com
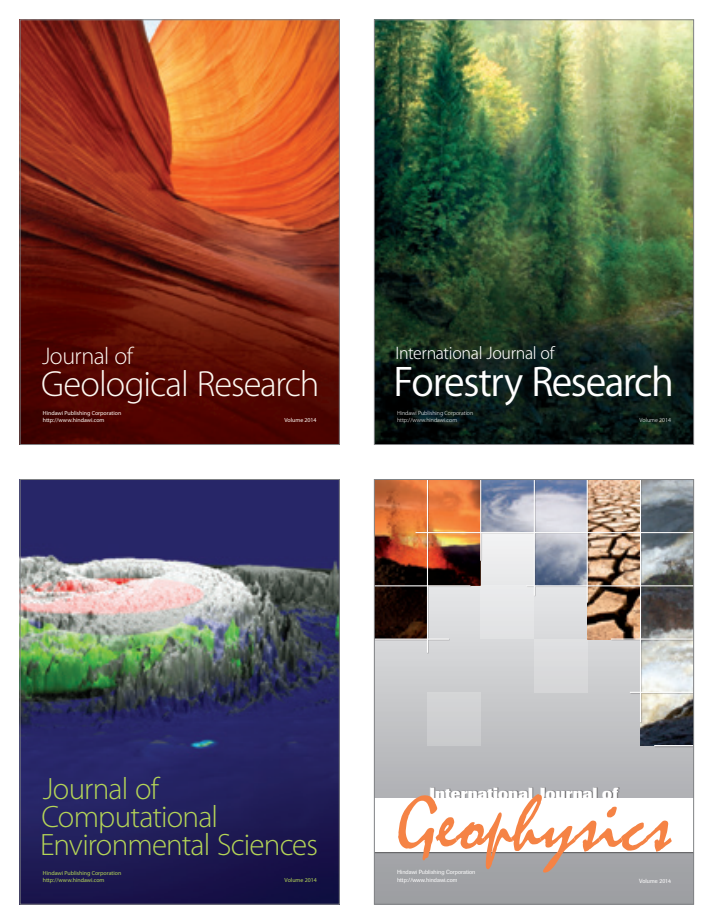
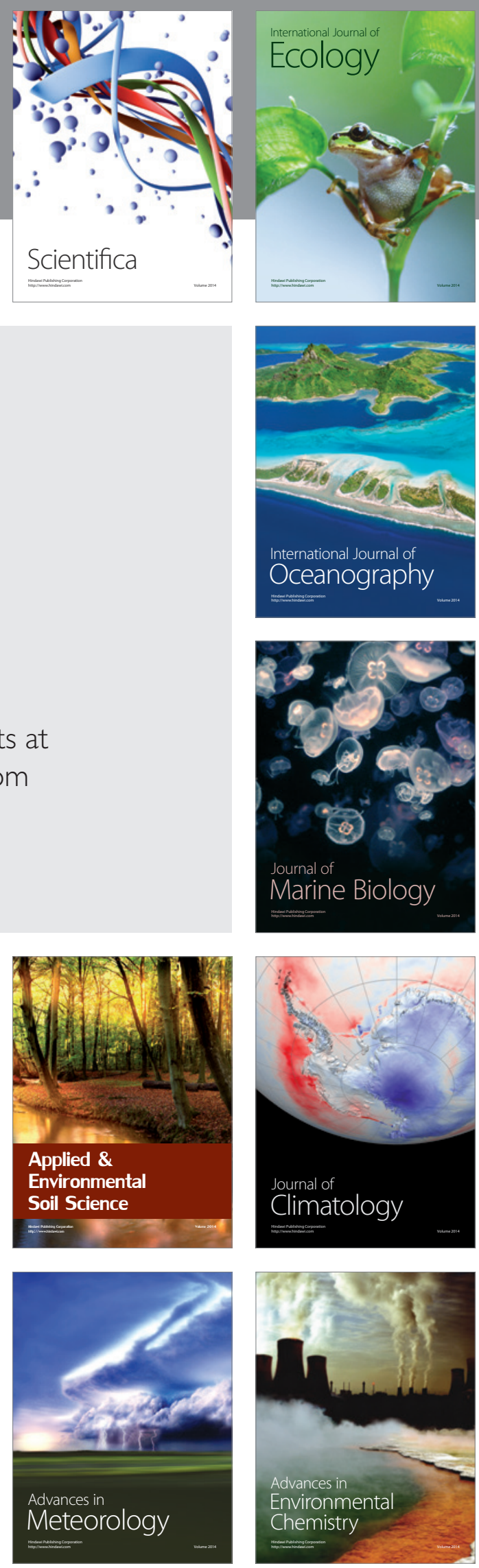